\title{
Sanding the Wheels of Growth: Cheating by Economics and Business Students and 'Real World' Corruption
}

\author{
Aurora A. C. Teixeira
}

Published online: 25 July 2013

(C) Springer Science+Business Media Dordrecht 2013

\begin{abstract}
The relation between academic integrity and real world corruption is more often presumed than proven. Based on a sample of 7,602 students from 21 countries, it was found that academic cheating in the past is a predictor of the countries' current level of corruption. This reproducibility and persistence over time of dishonest behaviors highlights the danger of disregarding students cheating at university.
\end{abstract}

Keywords Cheating $\cdot$ Corruption $\cdot$ Ethics $\cdot$ Students $\cdot$ Universities

JEL-Codes $\cdot$ A13 $\cdot$ A22 $\cdot$ D73 $\cdot$ I25

\section{Introduction}

There is widespread agreement that corruption has become one of today's most pressing global and ethical problems (Johnson et al. 2011). ${ }^{1}$ Corruption is said to distort standards of merit and erode the respect of law (Hamir 1999), resulting in higher public investment and lower quality of infrastructure (Tanzi and Davoodi 1998), as well as holding back political and economic advancement (Klitgaard 1994).

The current credit-market meltdown and governance misbehavior has been fuelling reflections on the role of business schools and business educators. Education has an essential role to play in nurturing ethical business leaders and the global financial crisis has re-ignited further interest in management as a profession. As stressed by Mackness (2010), "[g]raduating fully informed and conscientious leaders in every business discipline is the first step in changing the way business gets done and creating a more sustainable world.". Indeed, in the aftermath of the financial crisis of 2008 and the current Eurozone crisis, there is not only a demand for a new

\footnotetext{
${ }^{1}$ Corruption might be defined as the use of public office for private gain (Rose-Ackerman 1978). Corruption is thus one aspect of governance which also relates to matters of transparency, accountability, political stability, social order, the rule of law and the like. These factors are likely to be interdependent (Blackburn 2012).
}

\footnotetext{
A. A. C. Teixeira $(\bowtie)$

CEF.UP, Faculdade de Economia, Universidade do Porto; INESC Porto, OBEGEF,

Rua Dr Roberto Frias, Porto, Portugal

e-mail: ateixeira@fep.up.pt
} 
standard of ethics and probity for business professionals but there are also calls for the redefinition of the purpose of business education.

It has been well-documented that a sizeable proportion of business school students routinely engage in cheating during their university experience (Teixeira and Rocha 2010). Research mainly focused on the US reality indicates that students intending to enter business fields are more likely than any other group of students to engage in cheating and other forms of academic dishonesty (McCabe and Trevino 1996). Premeaux (2005) further points out that cheating appears to be fairly ingrained in the culture of learning in business, this being “... quite unfortunate because today's business school students are tomorrow's business managers, not only in America but throughout the world." (Premeaux 2005: 416-7).

Indeed, if the same ethical standards prevail in the academic and business environments, and given that past behavior is a strong predictor of future behavior, it is likely that those who engage in unethical activities in the classroom will also engage in unethical activities in the business world (Grimes 2004). Not surprisingly, Lawson (2004) found a strong relationship between the students' propensity to cheat in an academic setting and their attitude toward unethical behavior in the business world. $\mathrm{He}$ argues that the long-held belief of students that unethical behavior is the norm in the business world is a cause for concern. Other authors (e.g., Caiden et al. 2001; Uprety 2000) further argue that where there is the general belief that "corruption is okay" or a normal practice, one will find corruption.

The aim of this paper is to assess whether cheating behavior by economics and business university students is indeed related to the 'real world' corruption of different countries. Based on individual responses from 7,602 economics and business students from 21 countries, we computed an index of (lagged) academic cheating (i.e., copying in exams in 2006) and related it to these countries' 2011 transparency indexes.

It was found that, after controlling for the countries' GDP per capita, higher levels of student cheating are associated with higher levels of 'real world' corruption.

\section{Data and Methodology}

Measuring cheating in academia is not an easy task and researchers have generally used their own information to gather data to assess this type of behavior (Nowell and Laufer 1997). A one-page questionnaire covering a range of questions focusing on the main determinants associated with copying in exams was devised and implemented in classes of 2 nd to 4 th year students from Economics and Business/Management courses enrolled in 46 schools located in 21 countries. $^{2}$

If the above 'prediction' is correct, one would expect that, controlling for the countries' level of development, the lagged (average) propensity to cheat be (significantly) correlated with the standard measures of the countries' corruption, namely the future (2011) Corruption Perception Index (CPI) released by the International Transparency (TI 2012), which reflects the perceptions of the degree of corruption as seen by business people and country analysts.

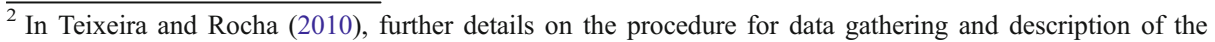
responses is provided.
} 
In order to test such a 'prediction', the following simple, base-line econometric model was used:

$$
\log _{\text {Cheating }}=\beta_{1}+\beta_{2} \log C P I_{i}+\beta_{2} \log G D P \text { per capita }_{i}+u_{i},
$$

with $i=1, \ldots, 21$.

\section{Results}

\section{Some Descriptive Results}

It is apparent that, at cross-country level, there is a non-linear significant relation between lagged cheating by economics and business undergraduates and the countries' CPI scores - countries that have both a very low ('high perceived corruption') and very high CPI score (i.e., 'are highly clean/transparent') present relatively low levels of student academic cheating (cf. Fig. 1).

In concrete, Nigeria and Argentina, which according to CPI are economies where corruption is rampant, and the Nordic countries, which are considered the least corrupt states in the world, are associated with low levels of misconduct at university, especially Sweden (4.5\%) and Denmark (5.1\%). The British Isles and New Zealand, being wellranked economies in terms of transparency, reveal low levels of academic cheating by economics and business students.

If we excluded Nigeria and Argentina, the relation between academic dishonesty and 'real world' transparency would be (in statistic terms) significantly negative (Pearson correlation coefficient estimate around -0.71 ), conveying the idea that countries where the propensity to cheat is high, the CPI scores are low; in other words, the corruption levels are high. These two countries are nevertheless interesting cases studies. Here, there is a widespread sense of the need to combat fraud and corruption. In a 2006 survey in Nigeria, it was revealed that $58 \%$ of the respondents identified corruption as the nation's most acute problem, while $42 \%$ considered it an important problem (IAP 2006). Likewise, in Argentina, several attempts have been made in the last decade to curb corruption both in the society as a whole, and in the education sector in particular (Hernandez 2004).
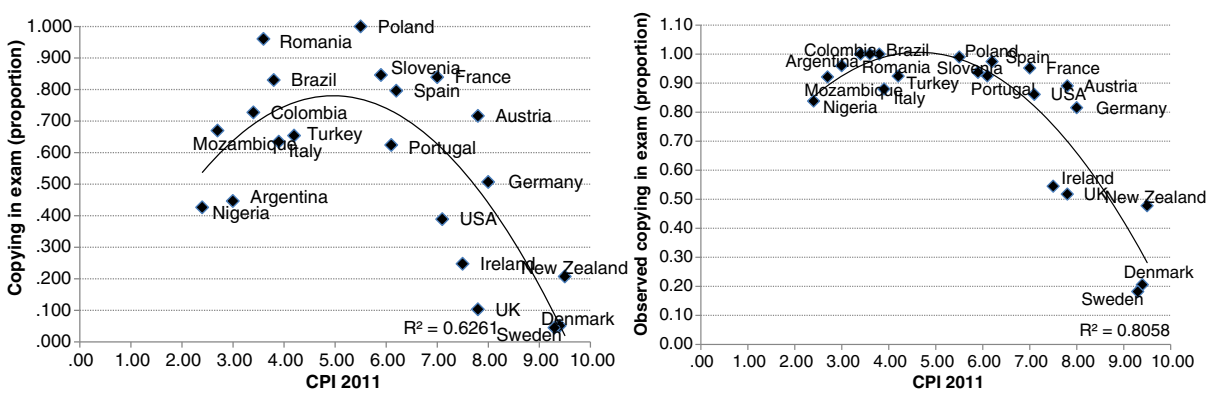

Fig. 1 Relation between cheating in academia and 'real world' corruption. Source: Calculations made by the author based on direct survey conducted in the periods February 2005-May 2006; CPI (TI 2012). Note: The Corruption Perceptions Index ranks countries/territories based on how corrupt their public sector is perceived to be. A country/territory's score indicates the perceived level of public sector corruption on a scale of $0-10$, where 0 means that a country is perceived as highly corrupt and 10 means that a country is perceived as very clean (see http://cpi.transparency.org/cpi2011/results/) 
Table 1 Regression results. Dependent variable: 2011 CPI in logarithm. OLS estimation

\begin{tabular}{llll}
\hline & $\begin{array}{l}\text { Model 1 } \\
\text { [Cheating=log of the index } \\
\text { of country average copying } \\
\text { at exams in 2006] }\end{array}$ & $\begin{array}{l}\text { Model 2 } \\
\text { [Cheating=log of the } \\
\text { frequency student } \\
\text { copying in 2006] }\end{array}$ & $\begin{array}{l}\text { Model 3 } \\
\text { [Cheating=log of the frequency } \\
\text { student observing other } \\
\text { copying in 2006] }\end{array}$ \\
\hline Cheating (2006) & $-0.151^{* *}$ & $-0.105^{* * *}$ & $-0.152^{* * *}$ \\
& {$[-2.551]$} & {$[-15.020]$} & {$[-24.576]$} \\
2011 GDP pc (log) & $0.316^{* * *}$ & $0.371^{* * *}$ & $0.363^{* * *}$ \\
Constant & {$[5.713]$} & {$[124.093]$} & {$[123.775]$} \\
Observations & Yes & Yes & Yes \\
Adjusted $\mathrm{R}^{2}$ & 0.720 & 7,139 students & 7,139 students \\
\hline
\end{tabular}

*** $\left(^{* *}\right)$ significant at $1 \%(5 \%)$; CPI - The Corruption Perceptions Index ranks countries/territories based on how corrupt their public sector is perceived to be. A country/territory's score indicates the perceived level of public sector corruption on a scale of $0-10$, where 0 means that a country is perceived as highly corrupt and 10 means that a country is perceived as very clean; GDP per capita - gross domestic product at purchasing power parity per capita, in a per capita basis, the value of all final goods and services produced within a country in a given year divided by the average (or midyear) population for the same year. Sources: CPI - in http://cpi.transparency.org/cpi2011/results/; Cheating-based on responses by 7,602 students, further details in Teixeira and Rocha (2010); 2011 GDP per capita-World Bank

\section{Econometric Results}

Table 1 shows the base-line regression results. The control variable, 2011 GDP per capita, displays the expected sign and is statistically significant at $1 \%$. Accordingly, higher level of economic development reflected in greater GDP per capita lowers corruption. This broadly conforms to the general indication in the literature (Goel and Ram 2013).

Significantly, the results reported in Table 1 show that cheating (i.e., copying in exams) in the past by each country's economics and business students has a negative influence on the (present) indicator of the country's transparency. The coefficient of the 2006 cheating variable is statistically significant at the $1 \%-5 \%$ level and indicates that if the cheating increases by one point, the country's future (within a 5-year period) transparency as measured by the CPI decreases by about $0.10-0.15$ points. $^{3}$

It is worth noting that despite the relevance of academic cheating for predicting countries' future corruption, the level of development of a country, as reflected in its GDP per capita, evidence an even stronger correlation with corruption. This, however, should come at no big surprise as higher levels of development (i.e., GDP per capita) are likely to convey increased political rights and civil liberties, in short, 'better institutions', which lower corruption significantly (Acemoglu and Johnson 2005; Lambsdorff 2006; Bertocchi and Guerzoni 2012; Mijiyawa 2013).

\footnotetext{
${ }^{3}$ It is important to underline that the issue of reverse causality was not demonstrated by the estimations (the coefficient of corruption failed to be statistical significant). Thus, the possibility that past real world corruption impacts on academic cheating did not emerged from the data.
} 


\section{Conclusion}

The results show that countries with high levels of cheating in Economics and Business university courses will tend to suffer from high real world corruption in the future. This finding is in line, for example, with the study by Lovett-Hooper et al. (2007). Based on an analysis of 154 introductory and upper-level psychology students enrolled at a midsized, Midwestern public university, these authors found that academic dishonesty (self-dishonesty, social falsifying, and plagiarism) is significantly predictive of a norm/rule-violating future. The results obtained clearly corroborate Lovett-Hooper et al.'s (2007) assumption that business and economics students who behave dishonestly at university could be expected to do so in other areas of their lives in the future, most notably in their future profession. The 'persistence' of cheating over time highlights the danger of disregarding students' dishonest behavior at university.

Economic and business schools, which are devoted to teaching economics and management as sciences, often do not acknowledge that every economic and business decision has societal repercussions (Bennis and O'Toole 2005; Basu 2010). Recent critiques on how the university, and most particularly business/management (Billsberry and Birnik 2010; Wright et al. 2013) and economics (Rubinstein 2006) schools, teach their students underline that it is fundamental to create ethical individuals, who are likely to become the competent leaders of countries and organizations in the future. It is not a mere process of transforming education in the professions, but rather the way we think about encouraging individuals to do the right thing in general (Poff 2007; 2010).

Acknowledgments I'll like to thank one anonymous reviewer for her/his valuable comments. I'm sincerely in debt to all the students who participated in the survey, and my fellow colleagues (from the schools located in the 21 countries) who generously made this research possible.

\section{References}

Acemoglu, D., \& Johnson, S. (2005). Unbundling institutions. Journal of Political Economy, 113(5), 949-995.

Basu, K. (2010). The moral basis of prosperity and oppression: altruism, other-regarding behaviour and identity. Economics and Philosophy, 26, 189-216.

Bennis, W., O’Toole, J. (2005). "How business schools lost their way", Harvard Business Review, 83(5): 96-104+154.

Bertocchi, G., \& Guerzoni, A. (2012). Growth, history, or institutions: What explains state fragility in subSaharan Africa? Journal of Peace Research, 49(6), 769-783.

Billsberry, J., \& Birnik, A. (2010). Management as a contextual practice: the need to blend science, skills and practical wisdom. Organization Management Journal, 7, 171-178.

Blackburn, K. (2012). Corruption and development: explaining the evidence. The Manchester School, 80(4), $401-428$.

Caiden, E. G., Dwivedi, P. O., Jabbra, J. (2001). Where Corruption Lives, Kumarian Press, Bloomfield, Ct.

Goel, R. K., \& Ram, R. (2013). Economic uncertainty and corruption: Evidence from a large cross-country data set. Applied Economics, 45(24), 3462-3468.

Grimes, P. (2004). Dishonesty in academics and business: a cross-cultural evaluation of student attitudes. Journal of Business Ethics, 49, 273-290.

Hamir, M. A. (1999). Keynote Address. In K. Frimpong \& G. Jacques (Eds.), Corruption, Democracy and Good Governance in Africa: Essays on Accountability and Ethical Behaviour (pp. 1-8). Gaborone: Lentswe La Lesedi.

Hernandez, S. (2004). “Combating Corruption in Argentina”, in http://www.elauditor.info/files/50a6dd3b5f869.pdf. Accessed on July 2013.

IAP - Independent Advocacy Project (2006). "Corruption is Nigeria’s Major Problem”, in http://www.indadvocacy-project.org/Press \%20Statements.htm.

Johnson, N. D., La Fountain, C. L., \& Yamarik, S. (2011). Corruption is bad for growth (even in the United States). Public Choice, 147, 377-393. 
Klitgaard, R. (1994). A framework for a country programme against corruption. In F. Galtung (Ed.), Accountability and transparency in international development: The launching of transparency international (pp. 55-73). Berlin: Laserline GmbH.

Lambsdorff, J. G. (2006). Causes and consequences of corruption: what do we know from a cross-section of countries? In S. Rose-Ackerman (Ed.), International Handbook of the Economics of Corruption (pp 351). Cheltenham, UK: Edward Elgar.

Lawson, R. (2004). "Is classroom cheating related to business students' propensity to cheat in the "real world"? Journal of Business Ethics, 49, 189-199.

Lovett-Hooper, G., Komarraju, M., Weston, R., \& Dollinger, S. J. (2007). Is plagiarism a forerunner of other deviance? Imagined futures of academically dishonest students. Ethics \& Behavior, 17(3), 323-336.

Mackness, J. (2010). “Are business schools to blame for the financial crisis?”, Business Ethics: The Magazine of Corporate Responsibility, May 7, 2010, in http://business-ethics.com/2010/05/07/1146-are-businessschools-to-balme-for-the-financial-crisis/, accessed on 26 July 2012.

McCabe, D. L., \& Trevino, L. K. (1996). What we know about cheating in college. Change, $29-33$.

Mijiyawa, A. G. (2013). Determinants of property rights institutions: survey of literature and new evidence. Economics of Governance, 14(2), 127-183.

Nowell, C., \& Laufer, D. (1997). Undergraduate student cheating in the fields of business and economics. The Journal of Economic Education, 28, 3-12.

Poff, D. (2007). Duties owed in serving students: the importance of teaching moral reasoning and theories of ethical leadership in educating business students. Journal of Academic Ethics, 5, 25-31.

Poff, D. (2010). Ethical leadership and global citizenship: considerations for a just and sustainable future. Journal of Business Ethics, 93, 9-14.

Premeaux, S. R. (2005). Undergraduate student perceptions regarding cheating: tier 1 versus tier 2 AACSB accredited business schools. Journal of Business Ethics, 62, 407-418.

Rose-Ackerman, S. (1978). Corruption: A study in political economy. New York: Academic.

Rubinstein, A. (2006). A sceptic's comment on the study of economics. The Economic Journal, 116(March), C1-C9.

Tanzi V., Davoodi, H. (1998). "Roads to nowhere: How corruption in public investment hurts growth", in Transparency International and the International Bank for Reconstruction and Development (ed.), New Perspectives on Combating Corruption, Transparency International and the International Bank for Reconstruction and Development, Washington, pp. 33-42.

Teixeira, A. A. C., \& Rocha, M. F. (2010). Cheating by economics and business undergraduate students: an exploratory international assessment. Higher Education, 59(6), 663-701.

TI (2012). Corruption Perception Index 2011. Berlin, Germany: Transparency International.

Uprety, H. (2000). Chaos and complexity of corruption. In R. Khanal (Ed.), Transparency and accountability against corruption in Nepal (pp. 27-37). Kathmandu: Modern Printing Press.

Wright, R. P., Paroutis, S. P., \& Blettner, D. P. (2013). How useful are the strategic tools we teach in business schools? Journal of Management Studies, 50(1), 92-124. 